\title{
Epidemiology and Molecular Characterization of Causative Agents of Bovine Tuberculosis in Ruminants
}

\author{
Ashenafi $D^{1}$, Mamo $\mathbf{G}^{1}$, Ameni $\mathbf{G}^{2}$ and Simenew $\mathrm{K}^{1,3 *}$ \\ ${ }^{1}$ College of Veterinary Medicine and Agriculture, Addis Ababa University, Debre Zeit, Ethiopia \\ ${ }^{2}$ Aklilu Lemma Institute of Pathobiology, Addis Ababa University, Addis Ababa, Ethiopia \\ ${ }^{3}$ Faculty of Agriculture and Rural Development, Dilla University, Dilla, Ethiopia
}

\begin{abstract}
A cross sectional study was conducted on 110 cattle and 397 small ruminants to determine the prevalence of bovine tuberculosis and possible risk factors, and to characterize the species of Mycobacteria circulating in Chifra district. Bacterial isolation and multiplex Polymerase Chain Reaction (PCR) were performed on milk and nasal swab samples of reactor animals. In tuberculin test, $13.64 \%$ cattle and $5.29 \%$ small ruminants were positive, and $31.58 \%$ and $25.00 \%$ were positive cultures on Löwenstein-Jensen media from milk and nasal swab samples, respectively. Based on PCR products, 12 were positive for genus Mycobacterium and none were positive for Mycobacterium tuberculosis complex or Mycobacterium avium-intracellulare complex group. The reactor rates observed for cattle under different body condition scores were poor (17.24\%), medium (6.25\%) and good (50.00\%) Body Condition Scores $(\mathrm{BCS})(P=0.025)$. The stepwise logistic regression analysis using independent variable medium BCS as a reference category indicated that good BCS (adjusted OR=4.29, 95\% Cl for OR=0.49-37.89) significantly affected tuberculin reactivity. This study showed that the prevalence of Single Comparative Intra-dermal Tuberculin (SCIDT) test positives and risk of acquiring the disease, increased with good BCS. Thus, more sensitive diagnostic techniques and control strategies should be considered on this risk group.
\end{abstract}

Keywords: Bovine tuberculosis; Molecular characterization; Single comparative intra dermal test

\section{Introduction}

Bovine Tuberculosis (BTB), caused by Mycobacterium bovis (M. bovis), is a well known zoonotic disease, which affects cattle worldwide, especially in developing countries, because of deficiencies in preventive and/or control measures, poor sanitation and health care [1,2]. It is of great socio-economic and public health importance and of significance in international trade of animals and animal products [3]. There were around 10 million new cases of human TB and 2 million deaths were reported annually [4], with sub-Saharan Africa displaying the highest annual risk of infection, probably aggravated by the expanding HIV epidemic and increasing drug resistance. Globally, TB causes more adult death than any other single infectious disease, $95 \%$ of cases and $98 \%$ of deaths occur in the developing world [5].

Ethiopia is among the 22 high TB-burden countries that accounts for $81 \%$ of estimated cases [6]. Over a third of the population has been exposed to TB. An estimated 377,030 Ethiopians (0.62\% of the population) have active TB of all kinds. In 2005 alone, the number of deaths in all cases of TB, including HIV positive patients was 56,456, and that of all cases, excluding HIV positive patients, were 42,508 deaths [7]. The prevalence of BTB in Ethiopia is high and molecular typing of $M$. bovis has also indicated the existence of unique strains [8]. Human infection due to M. bovis is thought to be mainly through drinking of contaminated or unpasteurized raw milk. The high prevalence of TB in cattle, close contact of cattle and humans, the habit of raw milk and meat consumption, and the increasing prevalence of HIV may all increase the potential for transmission of $M$. bovis and other Mycobacteria between cattle and humans [9].

Very limited research has been conducted in the Afar National Regional State (ANRS) to determine the prevalence rate of Bovine Tuberculosis, except for the reports of Yalelet [10] and Hussein [11], in Afambo and Amibara districts, respectively. Despite the large number of livestock population in the district, there is lack of information on
BTB in Chifra district. In the district, there are several risk factors that promote transmission of $M$. bovis from animals to animals and animals to humans, because of consumption of raw milk, close physical contact between human and livestock, frequent animal movements across the different districts, sharing of communal grazing lands and watering points by animals from different herds. Therefore, it is important to generate epidemiological data on BTB in Chifra district. Thus, the present study was conceived with the following objectives; to estimate the prevalence of BTB in cattle, goats and sheep in Chifra district, to assess possible risk factors for infection and transmission of the causative agents, and to characterize the species of Mycobacteria circulating in ruminants.

\section{Materials and Methods}

\section{Study area and population}

The study was conducted in Chifra district in administrative zone one of ANRS. It is one of the 32 districts in the ANRS and located 607 $\mathrm{km}$ from Addis Ababa. The district, with a total area of $12,444 \mathrm{~km}^{2}$ (sharing 13.13\% of the total area of the region), and divided into 2 agroclimatic zones: arid (Assgura), and semiarid (Mesigidoo), each sharing $72 \%$ and $28 \%$ of the total area of the district, respectively. The district shares boundary with Werebabo district of the Amhara Regional States in the West, on the South by Mile district of zone one, on the North by

*Corresponding author: Simenew K, College of Veterinary Medicine and Agriculture, Addis Ababa University, Debre Zeit, Ethiopia, P.O. Box 34, Tel: +251 911364193; Fax: +251 114 339933; E-mail: drsimenew@yahoo.com

Received November 27, 2012; Accepted December 28, 2012; Published January 02, 2013

Citation: Ashenafi D, Mamo G, Ameni G, Simenew K (2013) Epidemiology and Molecular Characterization of Causative Agents of Bovine Tuberculosis in Ruminants. J Bacteriol Parasitol 4:161. doi:10.4172/2155-9597.1000161

Copyright: (c) 2013 Ashenafi D, et al. This is an open-access article distributed under the terms of the Creative Commons Attribution License, which permits unrestricted use, distribution, and reproduction in any medium, provided the original author and source are credited. 
Ewa and Awra districts of zone four, and on the East by Dubti district of zone one of the ANRS as shown in figure 1.

The district receives a mean annual rainfall of $555 \mathrm{~mm}$ on the Western edge of the escarpment, and $225 \mathrm{~mm}$ on the lava plain and volcanic ash with three rainy seasons, where only camels and goats are reared. The maximum and minimum annual temperature of the area is $38^{\circ} \mathrm{C}$ and $21^{\circ} \mathrm{C}$, respectively. The altitude of the district ranges from 980 to $1000 \mathrm{~m}$, above sea level. The district has 19 pastoralist associations, of which six of them were agro-pastoralists and the remaining were purely pastoralists. $90 \%$ of the district population is leading a pastoral life by rearing camels, cattle, goats, and sheep. Central Statistical Agency [12], estimated that a total of 352,346 cattle, 342,286 sheep, 306,720 goats, 126,349 camels and 24,977 donkeys were kept in the district. Ruminants (cattle, sheep and goats) were the targeted study animals for this study.

\section{Study design, sample size and sampling techniques}

A cross sectional study design was used to determine prevalence of bovine tuberculosis on ruminants in Chifra district. The variable of interest was the occurrence of $\mathrm{TB}$ on live animals. The explanatory variables considered were pastoralist associations, age, body condition, herd/flock size, sex, reproductive status, parity number, lactating status, and species in case of small ruminants. The sample size was determined following the formula by Thrusfield [13], for simple random sampling, and the sample size required was calculated based on $95 \%$ confidence interval, 5\% desired precision. The calculated sample sizes were 110 and 397 for cattle and small ruminants, respectively, using the report of Yalelet, as reference prevalence rate.

Due to the clustering of animals/herds in a pastoralist association, a multi-stage random sampling technique was designed to select study animals. A complete list of pastoralist associations was obtained from the district head-quarter and five pastoralist associations were selected randomly, so as to study the prevalence of BTB and subsequently, milk and nasal swab samples were collected from reactor animals $(n=36)$, for bacterial isolation. At each pastoralist association, one sub-division was selected at random to represent the pastoralist association.

\section{Study methodology}

Animals belonging to selected pastoralist associations were

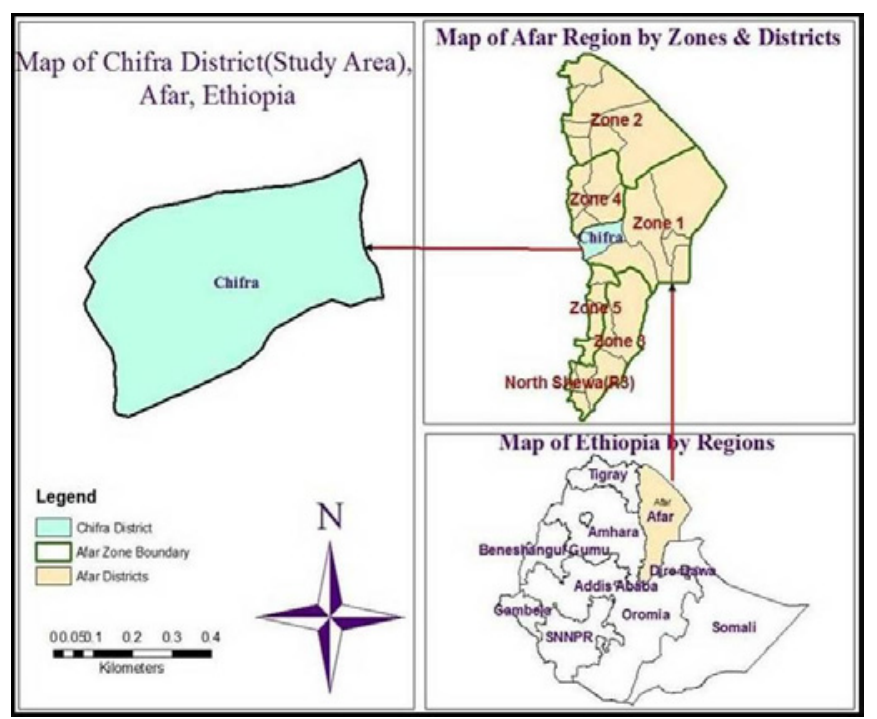

Figure 1: Map of Afar National Regional State and study area.

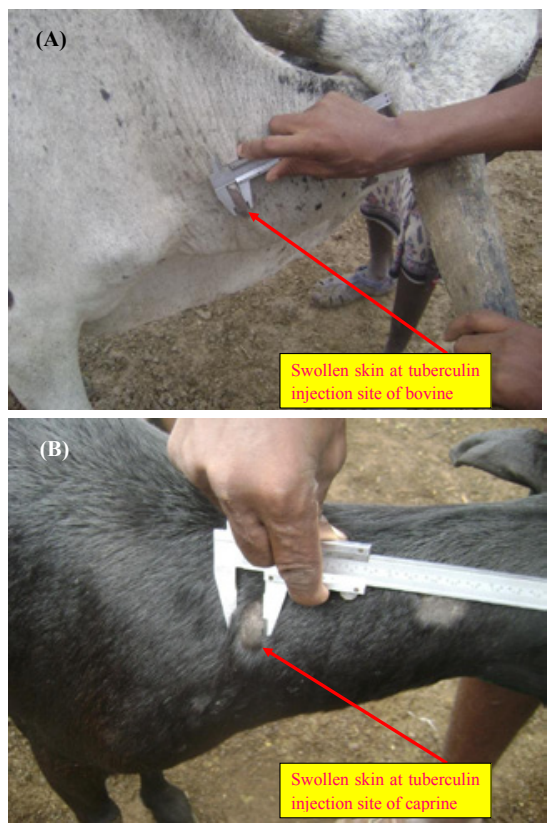

Figure 2: Swelling on the skin of bovine tuberculin reactor cow $(A)$ and goat (B), after 72 hours of injection with bovine PPD.

individually identified by names, which were previously given by their owners or assigned on the day of tuberculin inoculation, using identification numbers temporarily written on their back. Their age, Body Condition Score (BCS), sex, lactating status, reproductive status, and skin test measurements were recorded on prepared format sheet. Body condition score of cattle was determined using the method of Nicholson and Butterworth [14], and age determination using the method of Dyce et al. [15]. For small ruminants, BCS was based on the Langston University method [16], and age determinations were based on ESGPIP method $[17,18]$.

\section{Single Comparative Intra-dermal Tuberculin (SCIDT) Test}

Two sites on the skin of the right side of mid neck of the study animals, $12 \mathrm{~cm}$ apart, were shaved inspected, and skin thickness was measured in millimeters with digital caliper, before the injection of tuberculin. One site was injected with an aliquot of $0.1 \mathrm{ml}$ containing $2500 \mathrm{IU} / \mathrm{ml}$ bovine Purified Protein Derivative (PPD) (Veterinary Laboratories Agency, Addle stone, and Surrey KT15 3NB, U.K.). Similarly, $0.1 \mathrm{ml}$ of $2500 \mathrm{IU} / \mathrm{ml}$ avian PPD of the same agency was injected into the second site. After 72 hours, the skin thicknesses at both injection sites were measured (Figure 2). Animals showing increase in skin thickness at the injection site for bovine PPD of $2 \mathrm{~mm}$ more than the avian PPD were considered to be positive $[19,20]$.

\section{Mycobacterial culture}

Nasal swab samples were collected from both nostrils of reactor animals $(n=36)$ by using sterile swab, and placed in leak proof universal bottle, which contains sterile physiological saline solution and labeled with the animal's code number and date of collection. The samples were collected for isolation and identification of Mycobacterium species. The samples were kept at $4^{\circ} \mathrm{C}$, until being transported to Aklilu Lemma Institute of Pathobiology (ALIPB). The samples were cultured and decontaminated using $4 \% \mathrm{NaOH}$ solution, agitated in a vortex mixer for $15 \mathrm{~min}$ at room temperature, and centrifuged at $3000 \mathrm{rpm}$ for $15 \mathrm{~min}$. 
The supernatant was removed and the sediment suspended in $2 \mathrm{ml}$ of sterile physiological saline solution. One to two drops of $0.05 \%$ phenol red indicator was added to indicate $\mathrm{pH}$ change, and then neutralized using concentrated $(0.1 \mathrm{~N} \mathrm{HCl})$, until the color changed to yellow. The sediment was inoculated onto two slants of L-J media, one enriched with pyruvate, to enhance growth of $M$. bovis, and the other enriched with glycerol, to suppress growth of $M$. bovis and stimulate the growth of $M$. tuberculosis. Finally, isolates were harvested for molecular typing analysis by scrapping the growth from a slope into $200 \mu \mathrm{L}$ of sterile distilled water, and heating at $80^{\circ} \mathrm{C}$ for $45 \mathrm{~min}$ [21], and the harvest was kept at $-20^{\circ} \mathrm{C}$, until molecular analysis.

About $30 \mathrm{ml}$ milk samples of the last few streams of milk were aseptically drawn into sterile universal bottle from the four quarters of each PPD reactor animals $(\mathrm{n}=19)$ and transported immediately, and kept at $4^{\circ} \mathrm{C}$ at Chifra district health center, until they were transported. Then, they were transported to ALIPB for bacteriological examination and kept at $4^{\circ} \mathrm{C}$. The samples were added into sterile centrifuge tube and centrifuged at $3000 \mathrm{rpm}$ for $15 \mathrm{~min}$ at room temperature. The sediment was suspended to $2 \mathrm{ml}$ of sterile physiological saline solution and decontaminated with equal volume of sterilized $4 \% \mathrm{NaOH}$ solution, centrifuged, and neutralized using concentrated $\mathrm{HCl}$, using one or two drops of $0.05 \%$ phenol red as an indicator. After neutralization, the sediment from each sample was inoculated onto two slants of L-J media, as in nasal swabs. The culture was incubated at $37^{\circ} \mathrm{C}$, and was observed for bacterial growth for 8 weeks, according to Kazwala et al. [22].

\section{Multiplex Polymerase Chain Reaction}

Multiplex PCR as molecular technique differentiates MTBC from M. avium, $M$. intracellularae, and other mycobacterial species. Mycobacterial genus typing was conducted [23]. Heat killed AFB positive sample DNA was used as source of DNA template. The PCR targets the sequence of the genus Mycobacterium, within the 16S rRNA gene (G1,G2) sequences, within the hyper variable region of $16 \mathrm{~S}$ rRNA, that is known to be specific to $M$. intracellularae (MYCINT-F) and $M$. avium (MYCAV-R), and the MTB70 gene specific for MTBC (TB-A, TB-1B).

The primers used were MYCGEN-F, 5'-AGA GTT TGA TCC TGG CTC GA 3'; (35 ng/ $\mu \mathrm{L})$, MYCGEN-R, 5'-TGC ACA CAG GCC ACA AGG GA 3', (35 ng/ $\mu \mathrm{L})$; MYCAV-R, 5'-ACC AGA AGA CAT GCG TCT TG 3' (35 ng/ $\mu \mathrm{L})$; MYCINT-F, 5'-CCT TTA GGC GCA TGT CTT TA 3' (75 ng/ $\mu \mathrm{L}$ ); TB1-F, 5'-GAA CAA TCC GGA GTT GAC AA 3' (20 ng/ $\mu \mathrm{L})$; TB1-R, 5'-AGC ACG CTG TCA ATC ATG TA 3' (20 ng/ $\mu \mathrm{L})$ [24]. The reaction was carried out using thermal cycler (Applied Biosystems, GeneAMP 9700). The mastermix was heated for $10 \mathrm{~min}$ at $95^{\circ} \mathrm{C}$, further 35 cycles of $1 \mathrm{~min}$ at $95^{\circ} \mathrm{C}, 1 \mathrm{~min}$ at $61^{\circ} \mathrm{C}$, and $1.5 \mathrm{~min}$ at $72^{\circ} \mathrm{C}$; and 10 min at $72^{\circ} \mathrm{C}$. Each PCR tube consisted of $5.2 \mu \mathrm{L} \mathrm{H}_{2} \mathrm{O}$ Qiagen, $8 \mu \mathrm{L}$ Hot Star Taq Master Mix, $0.3 \mu \mathrm{L}$ of each of the six primers (concentration given above), and $5 \mu \mathrm{L}$ of DNA templates of samples or controls, making the total volume $20 \mu \mathrm{L}$. M. avium, M. intracellularae, H37Rv and 2122/97 M. bovis strain were used as positive controls, while $\mathrm{H}_{2} \mathrm{O}$ Qiagen was as a negative control. The product was electrophoresed in $2 \%$ agarose gel in TAE running buffer 10X. SYBR Safe at a ratio of 1:10 in $2 \%$ agarose gel, $100 \mathrm{bp}$ DNA ladder, and orange $6 \mathrm{X}$ loading dye were used in gel electrophoresis. All members of the genus Mycobacterium produce a band of $1030 \mathrm{bp}$, M. avium or subspecies, such as M. avium subsp. paratuberculosis produces a band of $180 \mathrm{bp}$, M. intracellularae a band of $850 \mathrm{bp}$, while members of MTBC produce a band with $372 \mathrm{bp}$.

\section{Data analysis}

Descriptive statistics, chi-square $\left(\chi^{2}\right)$, univariate and multivariate logistic regression were performed to analyze the data, using SPSS version 15 for Windows. For all analysis performed, 95\% CI and $P$-value $<0.05$ was set for statistical significance of an estimate.

\section{Results}

\section{Bovine tuberculosis in cattle}

Apparent prevalence and associated risk factors of bovine tuberculosis in cattle: Under the Single Comparative Intradermal Tuberculin test, screening of the tested animals for the other laboratory sample collection and processing of bacteriological and molecular characterization steps from the reactor animals. Of the associated risk factors considered, body condition score was found to be significant. The apparent prevalence of BTB based on a cut-off $>2 \mathrm{~mm}$ in cattle is presented in table 1.

Logistic regression analysis of risk factors with bovine tuberculosis positivity in cattle: As shown in table 2, the univariate and multivariable logistic regression analysis of the putative risk factors

\begin{tabular}{|c|c|c|c|c|}
\hline Factors (Variables) & $\begin{array}{c}\text { Noo of animals } \\
\text { tested }\end{array}$ & $\begin{array}{c}\text { No of reactors } \\
(\%)\end{array}$ & $\mathrm{X}^{2}$ Value & $P$-value \\
\hline \multicolumn{5}{|c|}{ Pastoralist associations } \\
\hline $\begin{array}{l}\text { G e r i r o n a } \\
\text { Wekello }\end{array}$ & 31 & $5(16.13 \%)$ & & \\
\hline $\begin{array}{l}\text { Anderkellona } \\
\text { Kelayitu }\end{array}$ & 62 & $8(12.90 \%)$ & & \\
\hline $\begin{array}{l}\text { W a n e b a n a } \\
\text { Robellie }\end{array}$ & 17 & $2(11.76 \%)$ & 0.24 & 0.89 \\
\hline \multicolumn{5}{|l|}{ Herd size } \\
\hline$x \leq 20$ & 73 & $10(13.70 \%)$ & & \\
\hline$x>20$ & 37 & $5(13.51 \%)$ & 0.01 & 0.98 \\
\hline \multicolumn{5}{|l|}{ Sex } \\
\hline Male & 25 & $2(8.00 \%)$ & & \\
\hline Female & 85 & $13(15.29 \%)$ & 0.87 & 0.35 \\
\hline \multicolumn{5}{|l|}{ Age in years } \\
\hline$x<2$ & 37 & $3(8.11 \%)$ & & \\
\hline $2 \leq X \leq 4$ & 36 & $6(16.67 \%)$ & & \\
\hline$X>4$ & 37 & $6(16.22 \%)$ & 1.45 & 0.48 \\
\hline \multicolumn{5}{|c|}{ Body condition scores } \\
\hline Poor & 58 & $10(17.24 \%)$ & & \\
\hline Medium & 48 & $3(6.25 \%)$ & & \\
\hline Good & 4 & $2(50.00 \%)$ & 7.36 & 0.03 \\
\hline \multicolumn{5}{|l|}{ Lactating status } \\
\hline Heifer & 34 & $3(8.82 \%)$ & & \\
\hline Lactating & 28 & $5(17.86 \%)$ & & \\
\hline Non lactating & 23 & $5(21.74 \%)$ & 1.98 & 0.37 \\
\hline \multicolumn{5}{|l|}{ Reproductive status } \\
\hline Heifer & 30 & $3(10.00 \%)$ & & \\
\hline Pregnant & 27 & $5(18.52 \%)$ & & \\
\hline Non pregnant & 28 & $5(17.86 \%)$ & 1.01 & 0.60 \\
\hline \multicolumn{5}{|l|}{ Parity number } \\
\hline$X=0$ & 39 & $4(10.26 \%)$ & & \\
\hline $0<x \leq 2$ & 20 & $4(20.00 \%)$ & & \\
\hline$x>2$ & 26 & $5(19.23 \%)$ & 1.42 & 0.49 \\
\hline
\end{tabular}

Table 1: Association of assumed risk factors with single comparative intraderma tuberculin test positivity in cattle. 
Citation: Ashenafi D, Mamo G, Ameni G, Simenew K (2013) Epidemiology and Molecular Characterization of Causative Agents of Bovine Tuberculosis in Ruminants. J Bacteriol Parasitol 4:161. doi:10.4172/2155-9597.1000161

Page 4 of 6

showed no statistically significant differences on tuberculin reactivity among animals, within each group of variables.

\section{Bovine tuberculosis in small ruminants}

Apparent prevalenceand associated risk factors of bovine tuberculosis in small ruminants: The association of risk factors with tuberculin reactivity indicated a slight statistical significant difference between goat and sheep, in proportion of bovine tuberculin reactivity; while, other variables such as pastoralist associations, flock size, sex, age, BCS, parity levels, lactating and reproductive status of the animals did not show a statistically significant difference between each group considered (table 3 ), positive tuberculin reactor goat as shown in figure 2 .

Logistic regression analysis of risk factors with bovine tuberculosis positivity in small ruminants: Multivariable logistic regression analysis showed that goats had 9.23 OR of being bovine tuberculin reactor compared to sheep (adjusted $\mathrm{OR}=9.23$; 95\% CI: $1.13-75.11$ ), as shown in table 4.

\begin{tabular}{|c|c|c|c|c|}
\hline \multirow{2}{*}{$\begin{array}{c}\text { Factors } \\
\text { (Variables) }\end{array}$} & \multicolumn{2}{|c|}{ № of animals } & \multicolumn{2}{|c|}{ OR } \\
\hline & Examined & $\begin{array}{l}\text { Positive for } \\
\text { TB (\%) }\end{array}$ & Crude $(95 \% \mathrm{Cl})$ & $\begin{array}{c}\text { Adjusted (95\% } \\
\mathrm{Cl})\end{array}$ \\
\hline \multicolumn{5}{|c|}{ Pastoralist associations } \\
\hline $\begin{array}{l}\text { Gerirona } \\
\text { Wekello* }\end{array}$ & 31 & $5(16.13 \%)$ & 1 & 1 \\
\hline $\begin{array}{l}\text { Anderkellona } \\
\text { Kelayitu }\end{array}$ & 62 & $8(12.90 \%)$ & $0.77(0.23-2.59)$ & $0.59(0.14-2.53)$ \\
\hline $\begin{array}{l}\text { Wanebana } \\
\text { Robellie }\end{array}$ & 17 & $2(11.76 \%)$ & $0.69(0.12-4.02)$ & $0.47(0.06-3.39)$ \\
\hline \multicolumn{5}{|l|}{ Herd size } \\
\hline$X \leq 20^{\circ}$ & 73 & $10(13.70 \%)$ & 1 & 1 \\
\hline$x>20$ & 37 & $5(13.51 \%)$ & $0.98(0.31-3.12)$ & $0.9(0.24-3.37)$ \\
\hline \multicolumn{5}{|l|}{ Sex } \\
\hline Male $^{*}$ & 25 & $2(8.00 \%)$ & 1 & 1 \\
\hline Female & 85 & $13(15.29 \%)$ & $2.08(0.44-9.89)$ & $\begin{array}{c}1.68(0.27- \\
10.59)\end{array}$ \\
\hline \multicolumn{5}{|l|}{ Age (years) } \\
\hline \begin{tabular}{|l|l}
$X<2^{*}$ \\
\end{tabular} & 37 & $3(8.11 \%)$ & 1 & 1 \\
\hline $2 \leq X \leq 4$ & 36 & $6(16.67 \%)$ & $2.27(0.52-9.86)$ & $1.88(0.39-8.95)$ \\
\hline$x>4$ & 37 & $6(16.22 \%)$ & $2.19(0.5-9.53)$ & $1.83(0.36-9.35)$ \\
\hline \multicolumn{5}{|c|}{ Body condition scores } \\
\hline Poor & 58 & $10(17.24 \%)$ & 1 & 1 \\
\hline Medium & 48 & $3(6.25 \%)$ & $0.32(0.08-1.24)$ & $0.32(0.08-1.32)$ \\
\hline Good & 4 & $2(50.00 \%)$ & $4.8(0.6-38.23)$ & $4.29(0.40-37.89)$ \\
\hline \multicolumn{5}{|l|}{ Lactating status } \\
\hline Heifer ${ }^{*}$ & 34 & $3(8.82 \%)$ & 1 & \\
\hline Lactating & 28 & $5(17.86 \%)$ & $2.25(0.49-10.37)$ & \\
\hline Non lactating & 23 & $5(21.74 \%)$ & $2.87(0.61-13.45)$ & \\
\hline \multicolumn{5}{|c|}{ Reproductive status } \\
\hline Heifer* & 30 & $3(10.00 \%)$ & 1 & \\
\hline Pregnant & 27 & $5(18.52 \%)$ & $2.05(0.44-9.52)$ & \\
\hline $\begin{array}{l}\text { Non } \\
\text { pregnant }\end{array}$ & 28 & $5(17.86 \%)$ & $1.96(0.42-9.09)$ & \\
\hline \multicolumn{5}{|l|}{ Parity number } \\
\hline$X=0^{*}$ & 39 & $4(10.26 \%)$ & 1 & \\
\hline $0<X \leq 2$ & 20 & $4(20.00 \%)$ & $2.19(0.48-9.87)$ & \\
\hline$x>2$ & 26 & $5(19.23 \%)$ & $2.08(0.50-8.63)$ & \\
\hline
\end{tabular}

*Reference indicated as 1 in crude and adjusted odds ratios.

Table 2: Multivariable logistic regression analysis of tuberculin reactors with various host - related risk factors at $2 \mathrm{~mm}$ cut-off point in cattle.

\begin{tabular}{|c|c|c|c|c|}
\hline Factors (Variables) & $\begin{array}{c}\text { No of animals } \\
\text { tested }\end{array}$ & $\begin{array}{c}\text { No of } \\
\text { reactors (\%) }\end{array}$ & $\mathrm{X}^{2}$ Value & $P$ - Value \\
\hline \multicolumn{5}{|l|}{ Pastoralist associations } \\
\hline Gerirona Wekello & 89 & $2(2.25 \%)$ & & \\
\hline Anderkellona Kelayitu & 187 & $9(4.81 \%)$ & & \\
\hline Jarana Kontolla & 64 & $5(7.81 \%)$ & & \\
\hline Semsemina Addoo & 57 & $5(8.77 \%)$ & 3.92 & 0.27 \\
\hline \multicolumn{5}{|l|}{ Species } \\
\hline \begin{tabular}{l|l} 
Sheep \\
\end{tabular} & 77 & $1(1.30 \%)$ & & \\
\hline Goat & 320 & $20(6.25 \%)$ & 3.04 & 0.08 \\
\hline \multicolumn{5}{|l|}{ Flock size } \\
\hline$x<75$ & 206 & $11(5.34 \%)$ & & \\
\hline$x \geq 75$ & 191 & $10(5.24 \%)$ & 0.00 & 0.96 \\
\hline \multicolumn{5}{|l|}{ Sex } \\
\hline Male & 54 & $3(5.56 \%)$ & & \\
\hline Female & 343 & $18(5.25 \%)$ & 0.01 & 0.93 \\
\hline \multicolumn{5}{|l|}{ Age (years) } \\
\hline$x \leq 2$ & 126 & $5(3.97 \%)$ & & \\
\hline $2<X \leq 5$ & 171 & $13(7.60 \%)$ & & \\
\hline$x>5$ & 100 & $3(3.00 \%)$ & 3.31 & 0.92 \\
\hline \multicolumn{5}{|l|}{ Body condition scores } \\
\hline \begin{tabular}{|l|l|} 
Poor \\
\end{tabular} & 188 & $12(6.38 \%)$ & & \\
\hline Medium & 122 & $8(6.56 \%)$ & & \\
\hline Good & 87 & $1(1.15 \%)$ & 3.82 & 0.15 \\
\hline \multicolumn{5}{|l|}{ Lactating status } \\
\hline Lamb/kid & 48 & $2(4.17 \%)$ & & \\
\hline Lactating & 198 & $12(6.06 \%)$ & & \\
\hline Non lactating & 97 & $4(4.12 \%)$ & 0.62 & 0.73 \\
\hline \multicolumn{5}{|l|}{ Reproductive status } \\
\hline \begin{tabular}{l|l} 
Lamb/kid \\
\end{tabular} & 31 & $1(3.23 \%)$ & & \\
\hline Pregnant & 111 & $5(4.50 \%)$ & & \\
\hline Non pregnant & 201 & $12(5.97 \%)$ & 0.59 & 0.75 \\
\hline \multicolumn{5}{|l|}{ Parity number } \\
\hline$x \leq 1$ & 107 & $7(6.54 \%)$ & & \\
\hline $1<x \leq 3$ & 102 & $6(5.88 \%)$ & & \\
\hline$x>3$ & 134 & $5(3.73 \%)$ & 1.06 & 0.59 \\
\hline
\end{tabular}

Table 3: Association of assumed risk factors with single comparative tuberculin test positivity in small ruminants.

\section{Bacteriological culture and polymerase chain reaction}

Mycobacteriological examination: Mycobacteriological culture examination on samples from SCIDT test tuberculin reactor animals (cattle, $\mathrm{n}=15$ and small ruminants, $\mathrm{n}=21$ ) showed that $31.58 \%$ (6) and 25\% (9) were culture positives from milk and nasal swab samples, respectively. Acid fast bacilli were confirmed in all of culture positive colonies.

Genus typing (Multiplex-Polymerase Chain Reaction) for Mycobacterium species: Based on electrophoresis separation of PCR products, 12 are positive for genus Mycobacterium and none were positive for MTBC or Mycobacterium avium-intracellulare complex (MAC) group. They are Non-tuberculosis Mycobacteria (NTM) (Figure 3). Numbers 5, 6, 7 and 8 are milk, and 9 and 10 are nasal swab samples from cattle. Also, numbers 11 and 12 are nasal swab, and 13, 14, 15, 16, 17,18 and 19 are milk samples from small ruminants.

\section{Discussion}

The prevalence of BTB in the current study is similar to the report by Hussein [11] in cattle, and slightly higher than in goats of Amibara district. The overall prevalence obtained in cattle was higher than in some previous reports [10,25-28], in different pastoral areas of Ethiopia. 


\begin{tabular}{|c|c|c|c|c|}
\hline \multirow[b]{2}{*}{ Factors (Variables) } & \multicolumn{2}{|c|}{ № of animals } & \multicolumn{2}{|c|}{ OR } \\
\hline & Examined & $\begin{array}{c}\text { Positive for } \\
\text { TB (\%) }\end{array}$ & $\begin{array}{l}\text { Crude } \\
(95 \% \mathrm{Cl})\end{array}$ & $\begin{array}{l}\text { Adjusted } \\
(95 \% \mathrm{Cl})\end{array}$ \\
\hline \multicolumn{5}{|l|}{ Pastoralist associations } \\
\hline Gerirona Wekello* & 89 & $2(2.25 \%)$ & 1 & 1 \\
\hline Anderkellona Kelayitu & 187 & $9(4.81 \%)$ & $2.2(0.47-10.40)$ & $4.9(0.71-33.66)$ \\
\hline Jarana Kontolla & 64 & $5(7.81 \%)$ & $3.69(0.69-19.60)$ & $1.92(0.34-10.92)$ \\
\hline Semsemina Addoo & 57 & $5(8.77 \%)$ & $4.18(0.78-22.30)$ & $7.54(0.74-76.84)$ \\
\hline \multicolumn{5}{|l|}{ Species } \\
\hline Sheep ${ }^{*}$ & 77 & $1(1.30 \%)$ & 1 & 1 \\
\hline Goat & 320 & $20(6.25 \%)$ & $5.07(0.67-38.40)$ & $9.23(1.13-75.11)$ \\
\hline \multicolumn{5}{|l|}{ Flock size } \\
\hline$X<75^{*}$ & 206 & $11(5.34 \%)$ & 1 & 1 \\
\hline$x \geq 75$ & 191 & $10(5.24 \%)$ & $0.79(0.29-2.16)$ & $2.41(0.53-11)$ \\
\hline \multicolumn{5}{|l|}{ Sex } \\
\hline Male $^{*}$ & 54 & $3(5.56 \%)$ & 1 & 1 \\
\hline Female & 343 & $18(5.25 \%)$ & $0.94(0.27-3.31)$ & $0.64(0.16-2.43)$ \\
\hline \multicolumn{5}{|l|}{ Age (years) } \\
\hline$X \leq 2^{*}$ & 126 & $5(3.97 \%)$ & 1 & 1 \\
\hline $2<X \leq 5$ & 171 & $13(7.60 \%)$ & $1.2(0.69-5.74)$ & $1.74(0.58-5.21)$ \\
\hline$x>5$ & 100 & $3(3.00 \%)$ & $0.75(0.17-3.21)$ & $0.68(0.15-3.16)$ \\
\hline \multicolumn{5}{|l|}{ Body condition scores } \\
\hline Poor & 188 & $12(6.38 \%)$ & 1 & 1 \\
\hline Medium & 122 & $8(6.56 \%)$ & $1.03(0.41-2.60)$ & $1.04(0.40-2.71)$ \\
\hline Good & 87 & $1(1.15 \%)$ & $0.17(0.02-1.33)$ & $0.18(0.02-1.5)$ \\
\hline \multicolumn{5}{|l|}{ Lactating status } \\
\hline Lamb/kid* & 48 & $2(4.17 \%)$ & 1 & \\
\hline Lactating & 198 & $12(6.06 \%)$ & $1.48(0.30-6.86)$ & \\
\hline Non lactating & 97 & $4(4.12 \%)$ & $0.99(0.17-5.60)$ & \\
\hline \multicolumn{5}{|l|}{ Reproductive status } \\
\hline Lamb/kid* & 31 & $1(3.23 \%)$ & 1 & \\
\hline Pregnant & 111 & $5(4.50 \%)$ & $1.42(0.16-12.58)$ & \\
\hline Non pregnant & 201 & $12(5.97 \%)$ & $1.9(0.24-15.19)$ & \\
\hline \multicolumn{5}{|l|}{ Parity number } \\
\hline$x \leq 1^{*}$ & 107 & $7(6.54 \%)$ & 1 & \\
\hline $1<X \leq 3$ & 102 & $6(5.88 \%)$ & $0.89(0.29-2.75)$ & \\
\hline$x>3$ & 134 & $5(3.73 \%)$ & $0.55(0.17-1.80)$ & \\
\hline
\end{tabular}

*Reference category is indicated as 1 in crude and adjusted odds ratios.

Table 4: Multivariable logistic regression analysis of tuberculin reactors with various host-related risk factors at $2 \mathrm{~mm}$ cut-off point in small ruminants.

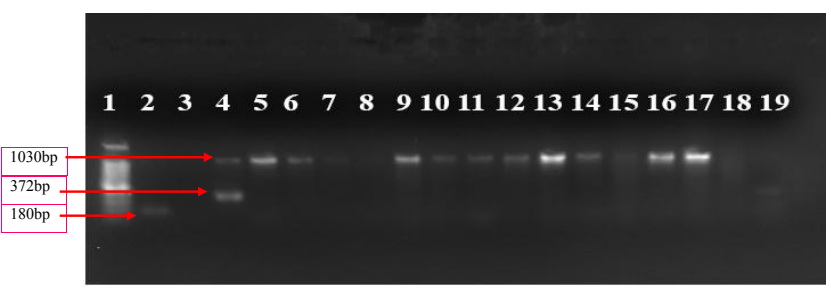

Figure 3: Gel electrophoresis separation of polymerase chain reaction products of multiplex Polymerase Chain Reaction typing of the genomic DNA of mycobacteria, isolated from milk and nasal swab samples of positive reactor animals run on $2 \%$ agarose gel. Lane: 1=a ladder of band at an interval of 100 bp DNA; $2=$ Mycobacterium avium-positive control; 3=Qiagene-water negative control; 4=Mycobacterium tuberculosis complex-positive control; 5, 6, 7, 9, 10,11,12,13,14,15, 16 and 17=positive samples for genus Mycobacterium; 8, 18 and 19=negative samples.

Similarly, a lower prevalence was recorded in Uganda, as reported by Inangolet et al. [29]. The differences of the reports from the present study might be attributed to the epidemiological factors that favor transmission of BTB in the Chifra district, as the district has a large area of communal grazing and watering points, high number of livestock from different districts of Afar region move seasonally into the district. This might increase the transmission of the diseases, and consequently, increase prevalence of the disease in the district.

On the other hand, the result of the present study was much lower than the higher prevalence of BTB reported in urban intensive dairy farms of Ethiopia, where Holstein and crossbreeds of cattle predominantly form the composition of the farms under intensive management system $[8,30]$. This difference might be mainly related to the intensive husbandry system practiced and breed susceptibility $[8,20,31,32]$.

The overall prevalence of BTB in small ruminants in the present study is in agreement with some reports [33,34]. The results of the present study was different from the report on goats and sheep of central Ethiopia using SCIDT, which showed a low prevalence of BTB [35], and from the report which indicated the absence of the disease in goats of Hamar pastoral district of southern Ethiopia [26]. This difference might be related to the difference in geographical location, in which the epidemiology of the disease might vary. The prevalence of TB in goats recorded by the present study is higher than the previous report of Yalelet [10] in Afambo and Dubti, and of Hussein [11], in Amibara districts of ANRS. An assumption to explain this fact is that, the Afar pastoralists in Chifra district keep large numbers of goats together with cattle in the same grazing pasture, and this might increase the risk of transmission of the disease from infected cattle to goats. It was reported that goats acquire TB when they have close contact with cattle and share pasture with infected cattle [36].

The higher prevalence of BTB in female than male cattle could be due to the small number of observation of male cattle, as the male animal population in pastoral society is minimal. These may reflect greater productivity stress and longer life span among female animals. This study revealed lower reactor rates of age $\leq 2$ years old, as compared to cattle of age $>2$ years old. As explained by different reports, including Radostits et al. [36], as age increases the probability of acquiring TB infection increases. The result was in agreement with previous studies where sheep TB has been reported [35,37-39]. Furthermore, in the multivariable logistic regression analysis, statistically significant difference was observed between goats and sheep.

In the present study, several animal level characteristics have been described as risk factors predisposing ruminants to BTB infection. However, none of the factors except BCS, in case of cattle, and species, in case of small ruminants, were found significantly associated with tuberculin reactivity of animals. Similarly, individual animal characteristics such as age, sex, pregnancy and lactation, were not significantly related with tuberculin reactivity of cattle.

The lower isolation rate of Mycobacteria may have resulted from reduced sensitivity of culture, arising from prolonged storage at field sites, and the freeze-thaw cycles that occurred during transportation and contamination of samples, as well as growth of other environmental Mycobacteria [40]. It is comparable with other findings [10,11], in which no growths of $M$. bovis from milk of cows positive to SCIDT test was reported. However, a predominant isolation of Non-tuberculosis Mycobacterium (NTM) from milk and nasal swab of tuberculin reactor animals from this study indicates the importance of these groups of Mycobacterium in the epidemiology of TB in Chifra pastoral district.

The current study supports the endemic nature of BTB, and further, indicates the importance of the disease in livestock of ANRS. Moreover since Afar pastoralists predominantly depend on consumption of raw 
animal products, including milk and meat, the current study highlights the potential zoonotic risk of BTB to humans in the region. In addition, identification of NTM from tuberculin reactor cattle and goats indicates their importance in the epidemiology of livestock TB, and which need to be further investigated, to design a control strategy in the region, in particular, and in the country, in general. Further study is recommended to extensively investigate the epidemiology of the diseases in wider sites, and larger sample sizes to identify the risk factors for infection and transmission of BTB among the livestock of ANRS, in order to design preventive and control strategies relevant to the pastoralists setting. Education and awareness creation among pastoralist community about the economic and public health significance of BTB will help to design a feasible community-based control programs.

\section{Acknowledgements}

The authors are thankful to all ALIPB laboratory staff (Mr. Hailu Getu, Mr. Adane Worku, Mr. Aboma Zewde and Mr. Nega Negussie) for their cooperation in the field and laboratory work. Heartfelt gratitude extends to all Chifra district communities for their unwavering support in many directions, especially to $\mathrm{Mr}$. Amin Arba, Mr. Abnet Sisay, Mr. Ali Arba and Mr. Wegris Haffa. Special thanks goes to friends and colleagues; Dr. Gezehagne E., Dr. Abreham, A. and Dr. Fasil, M., for their all rounded support during the study period.

\section{References}

1. Etter E, Donado P, Jori F, Caron A, Goutard F et al. (2006) Risk analysis and bovine tuberculosis, a re-emerging zoonosis. Ann N Y Acad Sci 1081: 61-73.

2. Smith $\mathrm{NH}$, Gordon SV, de la Rua-Domenech R, Clifton-Hadley RS, Hewinson RG (2006) Bottlenecks and broomsticks: the molecular revolution of Mycobacterium bovis. Nat Rev Microbiol 4: 670-681.

3. Cousins DV, Bastida R, Cataldi A, Quse V, Redrobe S, et al. (2003) Tuberculosis in seals caused by a novel member of Mycobacterium tuberculosis complex: Mycobacterium pinnipedii sp. nov. Int J Syst Evol Microbiol 53: 1305-1314

4. World Health Organization (WHO) (2010) Global tuberculosis control: surveillance, planning, and financing. Report, 2011.

5. Lawson L, Yassin MA, Ramsay A, Olajide I, Thacher TD, et al. (2006) Microbiological validation of smear microscopy after sputum digestion with bleach; a step closer to a one-stop diagnosis of pulmonary tuberculosis. Tuberculosis (Edinb) 86: 34-40.

6. http://apps.who.int/globalatlas/

7. World Health Organization (WHO) (2005) Global tuberculosis control: surveillance, planning and financing. WHO Report, Geneva: The Organization, Document WHO/HTM/TB/2005.

8. Ameni G, Aseffa A, Sirak A, Engers H, Young DB, et al. (2007) Effect of skin testing and segregation on the prevalence of bovine tuberculosis, and molecular typing of Mycobacterium bovis, in Ethiopia. Vet Rec 161: 782-786.

9. Ayele WY, Neill SD, Zinsstag J, Weiss MG, Pavlik I (2004) Bovine tuberculosis: an old disease but a new threat to Africa. Int J Tuberc Lung Dis 8: 924-937.

10. Yalelet W (2010) Epidemiology and species characterization of Mycobacterium tuberculosis complex in pastoralist and their livestock in two districts of the Afa region, North Eastern Ethiopia. MSc Thesis, Addis Ababa University, Faculty of Veterinary Medicine, Debre-zeit, Ethiopia.

11. Hussein N (2009) Study on Mycobacterium tuberculosis complex infection in livestock and humans in Amibara District of Afar Region. MSc Thesis, Addis Ababa University, Faculty of Veterinary Medicine, Debre-zeit, Ethiopia.

12. Central Statistic Agency (CSA) (2010) Report on livestock and livestock characteristics, Addis Ababa, Ethiopia.

13. Thrusfield M (2005) Veterinary Epidemiology. ( $3^{\text {rd }}$ edn), Black Well Science Ltd, 228-243.

14. Nicholson MJ, Butterworth MH (1989) Body condition scoring of zebu cattle. Addis Ababa: ILCA Publication, 15-25.

15. Dyce K, Sack W, Wensing D (1987) Teeth. In: Textbook of Applied Veterinary Anatomy. ( $2^{\text {nd }}$ edn), W. B. Saunders Company, Philadelphia, London, Toronto, Montreal, Sydney, Tokyo.

16. Langston University (2007) Body condition scores in goats taken from the meat goat production handbook, Langston University.

17. http://www.esgpip.org/PDF/Technical\%20bulletin\%20No8.html.
18. http://www.esgpip.org/PDF/Technical\%20bulletin\%20No.23.pdf

19. Ngandolo BN, Mueller B, Diguimbaye-Djaibe C, Schiller I, Marghaufe B, et al. (2009) Comparative assessment of fluorescence polarization and tuberculin skin testing for the diagnosis of bovine tuberculosis in Chadian cattle. Prev Vet Med 89: 81-89.

20. Ameni G, Hewinsen G, Abraham A, Young D, Vorderdermeir M (2008)Appraisa of interpretation criteria for the comparative intradermal tuberculin test for the diagnosis of tuberculosis in cattle in central Ethiopia. Clin Vaccine Immunol 15 1272-1276.

21. Cadmus S, Palmer S, Okker M, Dale J, Gover K, et al. (2006) Molecular analysis of human and bovine tubercle bacilli from a local setting in Nigeria. $J$ Clin Microbiol 44: 29-34.

22. Kazwala RR, Daborn CJ, Kusiluka LJM, Jiwa SFH, Sharp JM, et al. (1998) Isolation of Mycobacterial species from raw milk of pastoral cattle of Southern highlands of Tanzania. Trop Anim Health Prod 30: 233-239.

23. Mamo G, Bayleyegn G, Sisay Tessema T, Legesse M, Medhin G, et al. (2011) Pathology of camel tuberculosis and molecular characterization of its causative agents in pastoral regions of Ethiopia. PLos One 6: e15862.

24. Parsons LM, Brosch R, Cole ST, Somoskovi A, Loder A, et al. (2002) Rapid and simple approach for identification of Mycobacterium tuberculosis complex isolates by PCR-based genomic deletion analysis. J Clin Microbiol 40: 23392345.

25. Gumi B, Schelling E, Firdessa R, Aseffa A, Tschopp R, et al. (2011) Prevalence of bovine tuberculosis in pastoral cattle herds in the Oromia region, southern Ethiopia. Trop Anim Health Prod 43: 1081-1087.

26. Tschopp R, Aseffa A, Schelling E, Berg S, Hailu E, et al. (2010) Bovine tuberculosis at the wildlife-livestock-human interface in Hamer woreda, South Omo, Southern Ethiopia. PLoS One 5: e12205.

27. Laval G, Ameni G (2004) Prevalence of bovine tuberculosis in zebu cattle unde traditional animal husbandry in Boji district of western Ethiopia. Revue Méd Vét 155: 494-499.

28. Ameni G, Wudie A (2003) Preliminary study on bovine tuberculosis in Nazareth municipality abattoir of central Ethiopia. Bull Anim Health Prod 51: 125-132.

29. Inangolet FO, Demelash B, Oloya J, Opuda-Asibo J, Skjerve E (2008) A crosssectional study of bovine tuberculosisin the transhumant and agro-pastora cattle herds in the border areas of Katakwi and Moroto districts,Uganda. Trop Anim Health Prod 40: 501-508.

30. Ameni G, Bonnet P, Tibbo M (2003) A cross-sectional study of bovine tuberculosis in selected dairy farms in Ethiopia. J Appl Anim Res Vet Med 1: 253-258.

31. Tsegaye W, Aseffa A, Mache A, Mengistu Y, Berg S, et al. (2010) Conventiona and molecular epidemiology of bovine tuberculosis in dairy farms in Addis Ababa City, the capital of Ethiopia. J Appl Res Vet Med 8: 143.

32. Ameni G, Amenu K, Tibbo M (2000) Bovine Tuberculosis: Prevalence and risk factor assessment in cattle owners in wuchale-jida district, Central Ethiopia. Int J Appl Res Vet Med 1: 1-13.

33. Hiko A, Agga GE (2011) First-time detection of Mycobacterium species from goats in Ethiopia. Trop Anim Health Prod 43: 133-139.

34. Tafess K, Dawo F, Sori T, Ameni G (2011) Prevalence of caprine tuberculosis in Mid-Rift valley area of Oromia, Ethiopia. Afr J Microbiol Res 5: 1473-1478.

35. Tschopp R, Bobosha K, Aseffa A, Schelling E, Habtamu M, et al. (2011) Bovine tuberculosis at a cattle-small ruminant-human interface in Meskan, Gurage region, Central Ethiopia. BMC Infect Dis 11: 318

36. Radostits OM, Gay CC, Blood DC, Hinchelift KW (2000) Disease caused byMycobacterium. In: Veterinary Medicine: A Text Book of Disease of Cattle, Sheep, Pig, Goat and Horses, $9^{\text {th }}$ edn, Harcourt Publisher Ltd., London.

37. Muñoz Mendoza M, Juan Ld, Menéndez S, Ocampo A, Mourelo J, et al. (2012 Tuberculosis due to Mycobacterium bovis and Mycobacterium caprae in sheep. Vet J 191: 267-269.

38. Houlihan MG, Williams SJ, Poff JD (2008) Mycobacterium bovis isolated from a sheep during routine surveillance. Vet Rec 163: 94-95.

39. Marianelli C, Cifani N, Capucchio MT, Fiasconaro M, Russo M, et al. (2010) A case of generalized bovine Tuberculosis in a sheep. J Vet Diagn Invest 22 445-448.

40. Cleaveland S, Shaw DJ, Mfinanga SG, Shirima G, Kazwala RR, et al. (2007) Mycobacterium bovis in rural Tanzania: Risk factors for infection in human and cattle populations. Tuberculosis $87: 30-43$. 